\title{
JEROLIM SMEĆA - PUKOVNIK MLETAČKIH PREKOMORSKIH PJEŠAČKIH POSTROJBI (DRUGA POLOVICA 18. STOLJEĆA)*
}

\author{
Lovorka ČORALIĆ \\ Maja KATUŠIĆ \\ Hrvatski institut za povijest \\ Zagreb, Hrvatska
}

\author{
UDK: 929 Smeća, J.:94(450 Venecija) \\ DOI: http://doi.org/10.21857/ypn4oc8wp9 \\ Izvorni znanstveni rad \\ Prihvaćeno: 1. veljače 2017.
}

U ovom radu, zasnovanom na proučavanju gradiva iz Archivio di Stato di Venezia i Državnog arhiva u Zadru, središnja istraživačka pozornost usmjerena je na vojnu karijeru Bokelja Jerolima Smeće. Prati se Smećin put u mletačkoj službi od kadeta i zastavnika četrdesetih godina 18. stoljeća, preko višegodišnjeg obnašanja službe kapetana i bojnika u prekomorskim pješačkim pukovnijama (Fanti Oltramarini) Benedikta Paskvalija i Nikole Scutarija, do završnih godina 18. stoljeća kada je Smeća stekao čin pukovnika. U prilozima se donose prijepisi nekih od popisa Smećina vojnog ljudstva u razmaku od 1765. do 1794. godine.

Ključne riječi: Jerolim Smeća, Kotor, Mletačka Republika, Fanti Oltramarini, vojna povijest, 18. stoljeće.

\section{UVOD: OPĆI PODATCI O MLETAČKIM PREKOMORSKIM JEDINICAMA}

Povijest mletačke vojske neraskidivo je povezana $s$ vojnom poviješću istočnojadranske obale, ponajprije s onim krajevima koji su se tijekom dugog niza stoljeća nalazili u sastavu Serenissime. Država koja je značajan dio svoje moći zasnivala na podizanju snažne vojne sile, djelatne kako na kopnu tako i na moru, iznimnu je pozornost posvećivala svojim prekomorskim postrojbama, novačenim od Istre do Mletačke Albanije i Grčke. ${ }^{1}$

* Ovaj rad je sufinancirala Hrvatska zaklada za znanost projektom broj 3675 .

1 O mletačkim vojnim snagama u ranom novom vijeku, posebice $s$ obzirom na postrojbe novačene na području istočnog Jadrana, vidi u: Giuseppe SABALICH, Huomeni d'arme di Dalmazia, Zara, 1909.; G. SABAlich, La Dalmazia guerriera, Archivio storico per la Dalmazia, anno III, vol. V, fasc. 30, Roma, 1928., 279 - 300; Arduino Berlam, Le milizie dalmatiche della Serenissima, Rivista dalmatica, god. XVI, fasc. 1, Zara, 1935., 47 - 58; Ennio Concina, Le trionfanti e invittissime armate Venete, Venezia, 1972.; John R. HALE, L'organizzazione militare di Venezia nel'500, Roma, 1990.; Francesco Paolo Favaloro, L'Esercito Veneziano del '700: Ricerche e schizzi, Venezia, 1995.; Lovorka Čoralić - Nedjeljka BALIĆ NIŽIĆ, Iz hrvatske vojne povijesti - Croati a cavallo i Soldati Albanesi, njihova bratovština i gradivo o njezinu djelovanju od 1675. godine do sredine XVIII. stoljeća, Zbornik Odsjeka za povijesne znanosti Zavoda za povijesne i društvene znanosti HAZU, 
Od 16., a ponajprije kroz 17. stoljeće izvori kao elitne postrojbe spominju Soldati Albanesi - konjaničke (laka konjica) i pješačke jedinice koje su ponajprije novačene na područjima u sastavu mletačke pokrajine Albania Veneta. U vodama sjevernog Jadrana aktivne su bile tzv. mornaričke postrojbe Barche armate contro Uscocchi koje su - kao što i sam naziv sugerira - formirane sa zadaćom nadziranja i zaštite od uskočkih i drugih gusarskih prepada. ${ }^{2}$

Tijekom 17. i 18. stoljeća za mletačke profesionalne kopnene postrojbe novačene duž istočnojadranskog posjeda u izvorima se ponajviše koristio naziv Croati a cavallo (Cavalleria Croati) - hrvatska laka konjica, te Oltramarini pješačke postrojbe, iako su iste formirane i spominjane i ranije. Osnutak Croati a cavallo može se dovesti u usku vezu s nadiranjima Osmanlija u 15. stoljeću i padom zadarsko-biogradskog zaleđa pod osmansku vlast tijekom 16. stoljeća te prelaskom tamošnjih hrvatskih plemića na mletački teritorij. Zadar kao glavno mletačko vojno uporište u Dalmaciji, ali i grad uz koji je i vezano osnivanje tih postrojbi, bio je u svim stoljećima bio važno središte njihova djelovanja, novačenja i obuke. Hrvatsko konjaništvo posebno je bilo djelatno tijekom 17. stoljeća, odnosno u doba Kandijskog (1645. - 1669.) i Morejskog rata (1684. - 1699.) kada su te postrojbe, predvođene domaćim zapovjednicima, ratovale

sv. 24, Zagreb, 2006., 71 - 130; Tea MAYнew, Dalmatia between Ottoman and Venetian Rule: Contado di Zara 1645-1718., Roma, 2008.; T. MAYHEw, Mletački vojnik na istočnoj obali Jadrana za Kandijskog rata (1645-1669), Spomenica Josipa Adamčeka, ur. Drago Roksandić i Damir Agičić, Zagreb, 2009., 243 - 262; Domagoj Madunić, Defensiones Dalmatiae: Governance and Logistics of the Venetian Defensive System in Dalmatia during the War of Crete (1645 - 1669), Doctoral thesis, Central European University Budapest 2012.; Josip VRANDEČić, Borba za Jadran u ranom novom vijeku: mletačko-osmanski ratovi u venecijanskoj nuncijaturi, Split, 2013.; Nikola MAR KULIN, Vojno poduzetništvo u Mletačkoj Dalmaciji i Boki za vrijeme Morejskog rata (1684. - 1699.), Radovi Zavoda za povijesne znanosti HAZU u Zadru, sv. 56, Zagreb - Zadar, 2014., 91 - 142.

2 O Soldati Albanesi usp. A. Berlam, Le milizie dalmatiche della Serenissima, 54; E. Concina, Le trionfanti e invittissime armate Venete, 79. O udjelu „albanskih“ postrojbi na istočnojadranskom dijelu bojišnice usporedi: L. Čoralić, Zadarski kapetan XVII. stoljeća - Ulcinjanin Dominik Katić, Zbornik Odsjeka za povijesne znanosti Zavoda za povijesne i društvene znanosti HAZU u Zagrebu, sv. 22, Zagreb, 2004., 213 - 233; L. ČorAlıć, Albanska obitelj Kruta i njezini zaslužni pojedinci - prilog poznavanju istočnojadranskih komunikacija u ranom novovjekovlju, Historijski zbornik, god. LXII, br. 2, Zagreb, 2009., 371 - 390; L. Čoralić, 'Benemerita nazione': albanski vojnici i časnici u Zadru (XVI. - XVIII. st.), Zbornik Odsjeka za povijesne znanosti Zavoda za povijesne $i$ društvene znanosti HAZU, sv. 27, Zagreb, 2009., 121 - 164. O Barche armate contro Uscocchi usp. Miroslav BertošA, Izazovi povijesnog zanata: lokalna povijest $i$ sveopći modeli, Zagreb, 2002., 41. Brojne podatke vidi u Bertošinoj sintezi Mletačka Istra u XVI i XVII stoljeću, sv. I-II, Pula, 1986. te u zbirci građe: Miroslav BertošA, Pisma i poruke istarskih rektora, sv. I, od 1607. do 1616., Monumenta spectantia historiam Slavorum Meridionalium, sv. 52, Zagreb, 1979. Usporedi i: Gligor Stanojević, Senjski uskoci, Beograd, 1973., 60 - 65; J. HALE, L'organizzazione militare, 317; E. CoNCINA, Le trionfanti e invittissime armate Venete, 34. 
na širem potezu dalmatinske bojišnice. Kao elitne borbene jedinice, hrvatski konjanici nisu ratovali samo na dalmatinskoj bojišnici već su - u nemaloj mjeri - njihove jedinice djelovale i duž cijele mletačke terraferme. Pripadnici lake hrvatske konjice isprva su, kako je kazano, pripadali iseljenu stanovništvu zavičajem sa širega zadarskog područja. S vremenom su u te postrojbe pristupali i žitelji iz drugih dijelova Dalmacije i Boke kotorske, ali i albanski i crnogorski iseljenici iz drugih dijelova Mletačke Albanije, ponajprije onog dijela koji se tada nalazio pod osmanskom vlašću. ${ }^{3}$

Nadalje, novačenja oltramarina zabilježena su već početkom 16. stoljeća i isprva su se odnosila na mornaričko pješaštvo, a od Kandijskog rata i na kopnenu vojsku, interventno i porezno redarstvo i posadu tvrđava. Izrazito mobilni, oltramarini su svoju najveću brojnost postigli u 17. i 18. stoljeću, kada su njihove pukovnije (regimente) i satnije (compagnie) djelovale od mletačke terraferme, preko dalmatinskih i bokeljskih uporišta, do grčkih otoka i Peloponeza. Kao i prethodno spomenuti hrvatski konjanici, i prekomorski pješaci imali su prevažnu ulogu u sustavu obrane Serenissime sve do posljednjih dana opstojanja Republike svetog Marka. ${ }^{4}$

Brojni su Bokelji, ali i časnici i vojnici zavičajem s budvansko-barskog područja, kao i iz unutrašnjosti Crne Gore, aktivno participirali u svim navedenim mletačkim postrojbama. Mnogi od njih su, poput Ivana i Rade Krapovića iz Maina, Budvanina Marka Antuna Bubića, Jurja Baranina, Kotorana Frana Buće i Tripuna Gregorine, Peraštana Tripuna Štukanovića, Frana i Nikole Viskovića, kao i brojnih drugih zaslužnih odvjetaka iz bokeljskih obitelji Buća, Bolica, Bujović, Burović, Bronza, Paskvali, Visković itd., obnašali najprestižnije mletačke vojne činove (pukovnici, generali), ${ }^{5}$ često su uvrštavani u red mletačkih

3 Podrobnije usporedi: A. Berlam, Le milizie dalmatiche della Serenissima, 56 - 58; E. Concina, Le trionfanti e invittissime armate Venete, 29 - 41; F. P. FAVAloro, L'Esercito Veneziano del '700: Ricerche e schizzi, 100 - 103; L. ČORALIĆ - N. BALIĆ NižIĆ, Iz hrvatske vojne povijesti - Croati a cavallo i Soldati Albanesi.

M. BERTošA, Izazovi povijesnog zanata, Zagreb, 2002., 41 - 42.

5 Usporedi: L. Čoralı́́ - M. KATUŠıć, Od afričke obale do dalmatinske prijestolnice - mletački general Marko Antun Bubić (1735. - 1802.), Zbornik Odsjeka za povijesne znanosti Zavoda za povijesne i društvene znanosti HAZU, sv. 28, Zagreb, 2010., 139 - 172; L. Čoralić - M. KATUšić, Crnogorac Rade Maina - mletački general u Zadru (druga polovica XVIII. st.), Povijesni prilozi, god. 29, sv. 39, Zagreb, 2010., 125 - 152; L. Čoralić - M. KATUŠić, Peraštanin Tripun Štukanović - pukovnik mletačkih oltramarina (druga polovica 18. st.), Anali Zavoda za povijesne znanosti HAZU u Dubrovniku, sv. 50, Zagreb - Dubrovnik, 2012., 385 - 410; L. Čoralić - M. KATUšić, Hrvatski vojnici u posljednjim danima Mletačke Republike - kapetan Nikola Bolica i njegovi Fanti Oltramarini, u: Ascendere historiam. Zbornik u čast Milana Krubeka, ur. Marija Karbić, Hrvoje 
vitezova svetog Marka, ${ }^{6}$ a za stečene zasluge dobivali su u investituru zemljišne posjede na novooslobođenim područjima. Proučavanje njihova životnog puta i djelovanja važna je sastavnica u razumijevanju vojne, ali i društvene povijesti ne samo njihovih matičnih područja već i mnogo šireg prostora istočnog Jadrana u razdoblju ranog novog vijeka.

Uz stručnu literaturu koja je prethodno spomenuta, temeljno gradivo koje govori o vojničkom djelovanju i postrojbama kojima su zapovijedali Bokelji pohranjeno je u Archivio di Stato di Venezia (dalje: ASV). Riječ je o arhivskoj zbirci pod nazivom Inquisitori sopra l'amministrazione dei pubblici ruoli (dalje: Inquisitori ... pubblici ruoli) u kojoj je sadržano više od tisuću svežnjeva (busta) u kojima se nalazi građa o vojnim postrojbama u 18. stoljeću, iako su ovdje uključeni i dokumenti koji se odnose i na starije razdoblje mletačke vojne povijesti (od početka 17. stoljeća). Kada je riječ o konkretnim postrojbama, za istraživače mletačke vojne povijesti (ponajprije u 18. stoljeću) od iznimne su važnosti popisi unovačenih vojnika i časnika raspoređenih u talijanske postrojbe (Reggimenti e compagnie italiane, 1668. - 1797.), oltramarinske postrojbe (Reggimenti e compagnie Oltramarini, 1604. - 1797.), hrvatske konjaničke postrojbe (Cavalleria Croati, 1700. - 1797.), postrojbe kirasira (Cavalleria corazzieri, 1715. - 1797.), mješovite postrojbe (Compagnie sciolte, 1741. - 1795.), postrojbe draguna (Cavalleria dragoni, 1702. - 1797.) te topničke postrojbe (Artiglieria, 1652. 1797.). Za proučavanje udjela vojnika i časnika zavičajem $s$ istočnog Jadrana u navedenim mletačkim borbenim jedinicama od posebne su važnosti postrojbe pješačkih postrojbi i hrvatske konjice, iako treba napomenuti da je njihov udio bio prisutan i u svim drugim navedenim vojnim snagama.

Kekez, Ana Novak i Zorislav Horvat, Zagreb, 2014., 197 - 208; L. Čoralić, Crmničanin Marko Đikanović - pukovnik mletačkih prekomorskih postrojbi (Fanti Oltramarini), Istorijski zapisi, god. 83, sv. 3-4, Podgorica, 2011., 63 - 86; L. Čoralić, Mletački pukovnik Ivan Krapović iz Maina (prva polovica 18. stoljeća), Arbivski zapisi, god. 18, sv. 2, Cetinje, 2011., 81 - 106; L. Čoralić, Mletački časnik Nikola Visković i sastav vojnoga ljudstva njegove prekomorske pukovnije početkom 18. stoljeća, Historijski zbornik, sv. 65/2, Zagreb, 2012., 365 - 385.

6 Usporedi: Radojka JanićiJević, Odlikovanja slavnih Bokelja u prošlosti kao dokaz njihovih postignuća u pomorskom ratovanju, navigaciji, privredi i diplomatiji, Godišnjak Pomorskog muzeja u Kotoru (dalje: GPMK), sv. 52, Kotor, 2004., 279 - 313; L. Čoralić, Kotorski plemići Nikola Paskvali i Bartul Pima - kavaljeri Svetoga Marka (1634.), Istorijski zapisi, sv. 79, br. 1-4, Podgorica, 2006., 75 - 84; L. ČORAlić, Kotorski plemići iz roda Bolica - Kavaljeri Svetoga Marka, Povijesni prilozi, god. 25, br. 31, Zagreb, 2006., 149 - 159; Piero PAzzI, I Cavalieri di San Marco: Storia documentata, Perasto, 2008.; L. Čoralıć, Bokeljski patriciji u mletačkoj vojnoj službi - Cavalieri di San Marco, Acta Histriae, sv. 16, Kopar, 2008., 137 - 154; L. Čoralı́́, Budvani - Vitezovi Svetoga Marka, Anali Zavoda za povijesne znanosti HAZU u Dubrovniku, sv. 46, Zagreb - Dubrovnik, 2008., $347-358$. 
Također, kao dodatan izvor, koji često korespondira $s$ prethodno spomenutom arhivskom zbirkom, možemo navesti i spise generalnih providura za Dalmaciju i Albaniju (dalje: GPDA) u Državnom arhivu u Zadru (dalje: HRDAZD) u kojima su sadržani prijepisi duždevih dukala ili odluka mletačkog Senata, kao i odluke aktualnih generalnih providura Dalmacije koje se odnose na podjeljivanje viših časničkih činova pojedincima te na upućivanje pojedinih postrojbi na određene vojne dužnosti (ratne i mirnodopske).

Središnja tema ovog priloga usmjerena je na djelovanje Peraštanina Jerolima Smeće, visokog časnika u postrojbama Fanti Oltramarini u drugoj polovici 18. stoljeća. Uz spomenuto gradivo iz mletačkog i zadarskog arhiva, u radu se - ponajprije u svezi s obitelji Smeća i njezinim djelovanjem u ranom novom vijeku - koriste postojeća saznanja iz historiografije, kao i podatci iz matičnih knjiga katedrale sv. Tripuna u Kotoru, pohranjene u tamošnjem Biskupskom arhivu (dalje: BAK). Težište rada usmjereno je na Smećino djelovanje od četrdesetih godina 18. stoljeća (kada se bilježi kao kadet i zastavnik), preko višegodišnjeg obnašanja čina kapetana i bojnika, pa sve do konca istog vijeka kada kao pukovnik zapovijeda vlastitom postrojbom (pukovnijom). U radu se podrobno analiziraju popisi časnika, dočasnika i vojnika iz compagnia kojima je Smeća osobno zapovijedao (kao kapetan ili kao pukovnik), a koji pružaju i niz dodatnih podataka o sastavu, strukturi i zavičajnom podrijetlu vojnika koji su tada činili mletačke prekomorske snage.

\section{OBITELJ SMEĆA}

Peraška obitelj Smeća (Smekja, Smechia, Smecchia, Smachia) pripadala je starom peraškom bratstvu (casada) Čizmai (Cismai), a u arhivskim se vrelima i historiografskim djelima učestalije spominje od 17 . stoljeća. ${ }^{7}$ Međutim, prvi u izvorima do sada pronađeni spomen obitelji Smeća potječe iz 14. stoljeća, točnije iz 1326. godine, a riječ je o ispravi kojom Stanica de Smechia potvrđuje isplatu duga Bogdaše, sina Stanice. ${ }^{8}$

Iako obitelj Smeća pripada istaknutijim peraškim obiteljima, nije do sada, poput primjerice Balovića, Bujovića, Viskovića ili Zmajevića, bila predmetom

\footnotetext{
Pavao Butorac, Kulturna povijest grada Perasta, Perast, 1999., 422; P. Pazzi, Kratki povijesnoumjetnički uvod u Boku Kotorsku s osvrtom na Budvu, Bar i Ulcinj, s. 1, 2010., 29.

8 Isprava je napisana 19. prosinca 1326. godine. Nekoliko godina kasnije (27. veljače 1335.) u priznanici o vraćenom dugu Todora Euticijeva spominje se Deva, kći Stanice de Smechia. Usp.: Antun MAYER, Kotorski spomenici, prva knjiga kotorskih notara od god 1326 - 1335., Zagreb, 1951., 94, 401.
} 
opsežnijih historiografskih analiza te je stoga u trenutnoj fazi istraživanja teško iznijeti podrobniji genealoški prikaz obitelji. Unatoč tomu, kao što će pokazati sljedeći redci, njihova uloga u pomorskom, društvenom i kulturnom životu Boke i Perasta, poglavito u 18. stoljeću - bila je neosporna.

Stoljeće ranije, krajem 16. stoljeća, u izvorima se spominje pomorac Tripun pok. Petra Smeće, i to u nizu isprava koje se odnose na pomorsko-trgovačka poslovanja - kupnju, prodaju i prijevoz robe u lukama duž Jadrana. Zabilježeni su i brojni trgovački ugovori sklopljeni s odvjetcima kotorskih plemićkih obitelji (Bolica, Jakonja, Drago), a zanimljiv je i podatak da je 1593. godine Tripun zbog dugovanja kotorskom plemiću Benediktu Paskvaliju, a kako bi izbjegao zatvor, istome predao brod sa svom brodskom opremom. Nadalje, prema ispravi iz 1594. godine Smeća se obvezao kotorskoj općini brodom Madonna de Scarpello prevesti teret soli. ${ }^{9}$

Prvi značajniji odvjetak obitelji bio je Vicko Petrov (1694. - 1762.) - jedan od najpoznatijih i najuspješnijih peraških pomorskih trgovaca u 18. stoljeću. Kao trgovački poduzetnik (suvlasnik broda) i kapetan trgovao je i plovio duž Jadranskog i Sredozemnog mora. Tako su od 1722. do 1756. godine zabilježena njegova brojna trgovačka putovanja - poglavito prijevoz žita - od grčkih luka na Kefaloniji, Zakintu, Krfu, zatim od Soluna do Lisabona, Toulona, Genove, Ibize, Ankone i Mletaka. Na tim je putovanjima plovio brodovima kojima je bio vlasnik i suvlasnik, a najpoznatiji od njih bila je nava Leon Coronato koja je postala svojevrsni simbol pomorskih pregnuća obitelji Smeća. ${ }^{10}$ Ista je nava 1741. godine prilikom prijevoza suhog grožđa sa Zakinta u London stradala $u$ oluji, slično kao i 1746. godine (24. do 27. veljače) u blizini španjolske obale kada je brodom zapovijedao Vickov sin Petar. ${ }^{11}$ Leon Coronato bio je teško oštećen prilikom požara 1747. ili početkom 1748. godine, prilikom čega je smrtno stradao Vickov brat Krsto. Spomen na preživjele oluje 1741. i 1746. godine u

9 Godine 1594. spominje i Tripunov sin Nikola. Usp. Anita MAžıBRADIĆ, Stara porodica Smekja iz Perasta i njeni posjedi, Boka, sv. 31, Herceg Novi, 2011., 186.

10 Uz navu Leon Coronato spominju se i trgovački brodovi San Luigi, Immacolata Concezione te Madonna del Rosario e San Giuseppe. Usp.: Nikola Čolak, Hrvatski pomorski regesti (Regesti marittimi croati), sv. I (Settecento, I parte: Navigazione nell'Adriatico), Padova, 1985., 313 - 316 , 319, 321; N. Čola K, Hrvatski pomorski regesti (Regesti marittimi croati), sv. II (Settecento, I parte: Navigazione nell'Adriatico), Padova, 1993., 264, 271; P. Butorac, Kulturna povijest grada Perasta, 91; A. Mažı BRAdić, Stara porodica Smekja, 175.

11 Brod je imao tri jarbola i bio je naoružan topovima i ostalim vatrenim oružje. Pramac i krmu krasio je lav s krunom koji je na krmi bio ukrašen i peraškim grbom i križem. Usp. P. Butorac, Kulturna povijest grada Perasta, 78; A. MAžIBRADIĆ, Stara porodica Smekja, 176. 
svetištu Gospe od Škrpjela čuvaju dvije votivne, bogato ukrašene srebrne pločice, od kojih je potonju (iz 1746.) dao izraditi Tripun Smeća. ${ }^{12}$

Upravo je za navedene uspješne trgovačko-pomorske podvige 14. prosinca 1748. godine mletački dužd Pietro Grimani Vicka Smeću, njegove zakonite muške potomke, kao i potomke pokojnog mu brata Krsta obdario titulom conte. ${ }^{13}$ Osim brata Krsta koji je sa suprugom Margaretom Zambella imao sinove Josipa i Matiju te kćeri Luciju, Mariju i Agnezu, izvori i literatura spominju i Vickovu braću Matiju i Luku. ${ }^{14}$ Krsto je bio pomorac te je tridesetih godina 18. stoljeća zabilježen kao kapetan nave Madonna del Rosario e San Giuseppe kojom je duž Jadrana (Ankona, Krf, Albanija) prevozio žito, vino i porculan. ${ }^{15}$

Osim kao vrsni pomorac, Vicko Smeća istaknuo se, uz barskog nadbiskupa Andriju Zmajevića, kao jedan od najvećih darivatelja bokeljskog svetišta Gospe od Škrpjela. Tako je 1738. zajedno s kapetanom Antunom Grubašem brodom prevozio materijal za obnovu svetišta. Također, polovicom 18. stoljeća u svetištu je sagradio terasu o čemu svjedoči i grb obitelji Smeća, odnosno casade Čazmai koji se nalazi na balustradi. Svetištu je poklonio i križ za relikviju sv. Križa, a njegovi baštinici zaslužni su za izgradnju mramornog oltara i raskošne pale sv. Roka. Vicko Smeća darivao je i druge peraške crkve. Upravo je on najzaslužniji za dolazak poznatog mletačkog arhitekta Giuseppea Beattija s kojim je 1739. godine sklopio ugovor o gradnji nove peraške župne crkve te ga je svojim brodom dovezao u Perast. Naposljetku, na posjedu u Baošićima je zajedno s braćom sagradio kapelicu u čast mučenika sv. Vicka i sv. Lovre. ${ }^{16}$

Ponajviše podataka o iznimnim materijalnim mogućnostima Vicka Smeće te njegovim potomcima saznajemo iz njegova oporučnog zapisa načinjenog

12 Prva votivna pločica (oluja iz 1741.) opisuje spašavanje mornara Šimuna Novakovića kojega su val i vjetar bacili s palube. Na drugoj votivnoj pločici detaljno se opisuje oluja koja je brod zadesila 150 milja od Zakinta 1746. godine. Sačuvana je i treća votivna pločica koja prikazuje navu Leon Coronato - potječe iz prve polovice 18. stoljeća, ali zbog oštećenja nije moguće saznati kontekst nastajanja. Uz votivne pločice u zbirci umjetnina crkve Gospa od Škrpjela čuvaju se i tri zavjetne slike koje prikazuju navu Leon Coronato. Usp.: Francesco Viscovich, Storia di Perasto dalla caduta della Repubblica Veneta al ritorno degli Austriaci, Trieste, 1898., 234; Anica KIsIć, Ex voto Adriatico: zavjetne slike hrvatskih pomoraca, Zagreb, 2000., 107 - 110; P. PAZZI, Kratki povijesno-umjetnički uvod u Boku Kotorsku, 83; A. MAŽI BRADIĆ, Stara porodica Smekja, 175 - 176.

13 F. Viscovich, Storia di Perasto, 277 - 278; P. Butorac, Kulturna povijest grada Perasta, 91; A. MAŽIBRAdić, Stara porodica Smekja, 176.

14 A. Mažı bRAdić, Stara porodica Smekja, 175.

15 N. Čolak, Hrvatski pomorski regesti, sv. II, 268, 272; Miloš I. MilošEvić, Nosioci pomorske privrede Perasta u prvoj polovini XVIII vijeka, Godišnjak Pomorskog muzeja u Kotoru, sv. 7, Kotor, 1958., 122.

16 P. Butorac, Kulturna povijest grada Perasta, 91, 406 - 407, 410, 425, 434, 442. 
8. kolovoza 1754. godine u Kotoru. ${ }^{17}$ Iz oporuke saznajemo da je Vicko Smeća raspolagao s kapitalom od 100000 dukata u nekretninama, novcu, pokretninama i kreditima. Između ostalog, posjedovao je kuću i zemljišne posjede u Perastu, Kotoru, Bijeloj, Đurićima te ljetnikovac u Baošićima. O velikom imetku i razgranatoj poslovnoj mreži svjedoči i činjenica da je Vicko trgovačke poslove i ulaganja obavljao preko svoje trgovačke kuće u Mletcima. Kao nasljednici imovine navode se sinovi Petar (1724. - 1767.) i Ivan Šimun koje je Vicko imao u braku sa suprugom Jelenom (Elenom). Oba Vickova sina krenula su očevim stopama te su postali glasoviti pomorci. Navedeno se posebice odnosi na Petra, koji je u bokeljskoj pomorskoj povijesti ostao ponajprije zapamćen kao prvi Bokelj koji je uplovio u Baltičko more (1746. godine) te uspostavio pomorske i trgovačke veze s lukama Danske, Rusije i Prusije. ${ }^{18}$ Trajni spomen na obiteljske pomorske i trgovačke poduhvate svakako je veličanstvena palača koju je u Perastu 1764. godine izgradio upravo Petar. Izgrađena korčulanskim kamenom, smatra se najvećom baroknom palačom u Boki kotorskoj. ${ }^{19}$ Izvori navode da je Petar imao suprugu Katarinu i djecu Vicka Vjenceslava, Frana i Tripuna. ${ }^{20}$

O Petrovu bratu Ivanu Šimunu i njegovu sinu Vicku Manseutu nemamo mnogo saznanja. ${ }^{21}$ Potonji je - nezadovoljan raspodjelom nasljedstva od 1764. do 1803. godine - vodio spor s bratićima Tripunom i Franom (Petrovim sinovima). Spor je završio na apelacijskom sudu u Padovi, ali nije poznato kako je u konačnici razriješen. ${ }^{22}$

Petrov sin Vicko Vjenceslav spominje se 1782. godine kao mletački konzul u Trstu. Tamo se sklonio i zaposlio kako bi umaknuo dužnicima u Mletcima te isplatio postojeće dugove. Budući da nije uspio isplatiti dugovanja, odstupio je od konzularne časti, a u svom je razrješenju naznačio da će se od vjerovnika skloniti u tuđinu. Prema nekim zapisima iz Mletaka je otišao u Rusiju, a posljednji trag o Vicku Vjenceslavu zabilježen je u Duchcovu u Češkoj, gdje se 1790. susreo s

17 Oporuku je detaljno analizirala A. MAŽı BRAdıć, Stara porodica Smekja, 176 - 184.

18 F. Viscovich, Storia di Perasto, 277; Vinko Foretić, Udio naših ljudi u stranim mornaricama i općim pomorskim zbivanjima kroz stoljeća, Pomorski zbornik povodom 20-godišnjice dana mornarice i pomorstva Jugoslavije, sv. 1., Zagreb, 1962., 306; P. Buto RAC, Kulturna povijest grada Perasta, 91; A. MAžı Bradić, Stara porodica Smekja, 175.

19 P. Butorac, Kulturna povijest grada Perasta, 421 - 422; Gracija Brajković, Antun Tomić, M. MilošEvić, Zoran RADimiR, Neki manje proučavani primjeri građanske i crkvene arhitekture spomeničkog karaktera u Kotorskoj opštini, Godišnjak Pomorskog muzeja u Kotoru, sv. 25-26, 1987. - 1988., $104-105$.

20 A. MAŽı BRAdić, Stara porodica Smekja, 175.

21 Šimun se 1760. godine spominje kao član peraške bratovštine Presvetog Sakramenta, kao i njegov rođak Matija dvije godine kasnije. Usp.: P. Butorac, Kulturna povijest grada Perasta, 175.

22 A. MAŽı bradić, Stara porodica Smekja, 184. 
Giacomom Casanovom. Uz navedeno, poznat je i njegov književni pokušaj talijanskog prijevoda Gundulićeva djela Osman. ${ }^{23}$

Petrov sin conte Tripun živio je u Mletcima gdje je 1782. godine sklopio ugovor kojim braća Vincenzo Camillo i Pietro Scroffa daju obećanje da će njihova sestra Andrijana s njim sklopiti brak. ${ }^{24} \mathrm{Nije}$ sasvim razvidno je li on istovjetan Tripunu koji se spominje kao kartograf i autor karte Boke kotorske, Crne Gore i dijela Albanije, tiskane u Mletcima 1785. godine. ${ }^{25}$

Tripun Smeća (1775. - 1814.) studirao je pravo u Padovi, a životni je poziv usmjerio na sakupljanje narodnih pjesama i drugih izvora i zapisa o povijesti zavičaja. Autor je djela Sunto della Storia delle Bocche; napisao je i za tisak priredio tragediju Skenderbeg na talijanskom jeziku, kao i memoare o predaji Boke Austriji (Sulla dedizione delle Bocche di Cattaro a S. M. I. R. A.) koje je u knjizi Storia di Perasto otisnuo Francesco Visković. Neobjavljen je ostao i njegov prirodoslovni rječnik. ${ }^{26}$

Naposljetku, o materijalnoj snazi obitelji krajem 18. i početkom 19. stoljeća svjedoči podatak, odnosno tablica iz pera Tripuna Smeće (1802.) koja sadrži pregled kapitala koji su pojedine bokeljske obitelji imale u inozemstvu. U nasljedstvu obitelji Smeća tom se prilikom navode nekretnine u Mletcima, Chioggi i Zadru. ${ }^{27}$

\section{JEROLIM SMEĆA - KAPETAN U PUKOVNIJAMA PASKVALI I SCUTARI}

Prema dosadašnjim saznanjima historiografska djela ne donose spomen o Jerolimu Smeći, protagonistu ovog rada, te se stoga u daljnjem prikazu života i djela rečenog pukovnika oslanjamo isključivo na arhivsko gradivo iz mletačkog arhiva. Potvrdnicu pripadnosti bokeljskim Smećama daje nam popis stanovništva Kotora za podjelu soli iz sredine 1788 . godine. U njemu se kao nositelj kućanstva u kojemu su živjele još četiri (neimenovane) osobe spominje potpukovnik Jerolim Smeća. ${ }^{28}$ Kulturna povijest grada Perasta, 338 - 339; A. MAžı BRADIĆ, Stara porodica Smekja, 190.

24 A. MAŽı bradić, Stara porodica Smekja, 191.

25 A. MAŽı

26 P. Butorac, Kulturna povijest grada Perasta, 395; A. Mažıbradić, Stara porodica Smekja, 190.

27 F. Viscovich, Storia di Perasto, 235.

28 Đorđe Milović, Podaci o stanovništvu Kotora i Mula u 1788. godini, Godišnjak Pomorskog muzeja u Kotoru, sv. 17, 1969., 195. 
Vojnu karijeru Jerolima Smeće možemo sustavno pratiti od četrdesetih godina 18. stoljeća. Na osnovu podataka iz 1764. godine (imenovanje Smeće kapetanom) doznajemo da je u vojnu službu stupio kao kadet 1740 . godine. Potom je imenovan zastavnikom (Alfier), a 1761. godine priključen je pukovniji Kotoranina Benedikta Paskvalija (Paskvali Pima) ${ }^{29} \mathrm{u}$ činu natporučnika (Capitan tenente). ${ }^{30}$ Godine 1762 . Smeća je po prvi puta dobio priliku zapovijedati vlastitom satnijom. Naime, u to su vrijeme u pukovniji Benedikta Paskvalija dvije satnije ostale bez svojih zapovjednika, a broj vojnika u njima drastično je smanjen. Odlučeno je, kako stoji u ispravi koju je objavio generalni providur Dalmacije Pietro Michiel u Zadru 2. prosinca 1762., da natporučnik Jerolim Smeća sjedini rečene dvije satnije u jednu te preuzme zapovjedništvo u svojstvu governatore della sudetta compagnia. ${ }^{31}$

Smeća je u činu natporučnika ostao do 1764 . godine, kada je (25. kolovoza, temeljem odluke od 2. svibnja) objavljena već spomenuta dukala, sadržaj koje smo već navele govoreći o prvim početcima njegove vojne karijere. Iz sadržaja dukale doznajemo i podatke o Smećinim pretcima, zaslužnim za Serenissimu „i u doba rata i u doba mira“. Njegov je djed, također po imenu Jerolim, ${ }^{32}$ djelovao kao zapaženi mletački časnik (bojnik) u vrijeme Morejskog rata, kada je osobnim sredstvima naoružao i predvodio jednu satniju de fanti Albanesi sudditti Ottomani, koja je tijekom ratnih godina sudjelovala u kopnenim i pomorskim borbama. Jerolimov otac Ivan Frano ${ }^{33}$ također se istaknuo alla militar professione,

29 O istaknutom kotorskom plemiću Benediktu Paskvaliju (1704. - 1790.), koji je postigao briljantnu vojnu karijeru i stekao čin generala, usporedi: G. SABALICH, Huomeni d'arme di Dalmazia, 45; Šime PERIČIĆ, Neki Dalmatinci - generali stranih vojski, Radovi Zavoda za povijesne znanosti HAZU u Zadru, sv. 42, Zagreb - Zadar, 2000., 201 - 202; L. Čoralić - Nikola MARKULIN, Kotorski plemić Benedikt Paskvali (1704. - 1790.) - zapovjednik mletačkih prekomorskih pješačkih postrojbi, Acta Histriae (predano u postupak objavljivanja). Gradivo o prekomorskoj pukovniji Paskvali vidi u ASV, Inquisitori ... pubblici ruoli, b. 671-675. Fanti Oltramarini (1750. - 1774.).

30 HR-DAZD, GPDA, Pietro Michiel (1763. - 1765.), kut. 159, sv. I, fol. 163'-164 (Zadar, 25. VIII. 1764.). U ovome, kao i u većini dokumenata koje koristimo u radu, prezime Smeća najčešće je navedeno kao Smacchia.

31 HR-DAZD, GPDA, Pietro Michiel (1763. - 1765.), kut. 159, sv. I, fol. 9'-10. U ovom svežnju sadržani su i dokumenti koji se odnose na kraj 1762. godine.

32 Indirektan spomen djeda Jerolima Smeće nalazimo u matičnoj knjizi umrlih župe sv. Tripuna u Kotoru. Naime, 15. studenog 1724. preminula je Ana Smeća, supruga pokojnog Jerolima. Nadalje, 7. kolovoza 1785. u Kotoru je preminula Elena, supruga bojnika Jerolima (protagonist ovog rada) u 55. godini. Usp.: BAK, Matične knjige katedrale sv. Tripuna, Matična knjiga umrlih I (1643. 1731.), Matična knjiga umrlih III (1775. - 1823.).

33 Ivan Frano Antun u Kotoru se ženio dva puta. Prvi je brak sklopio 25. prosinca 1720. s Pavlom Kosović. Prilikom sklapanja tog braka otac Ivana Frana, bojnik Jerolim Smeća, naveden je kao pokojni. Drugi brak sklopio je 24. veljače 1723. s Pavlom Lazari. Usp.: BAK, Matične knjige katedrale sv. Tripuna, Matična knjiga vjenčanih II (1697. - 1824.). 
a njegovu je karijeru uspješno nastavio i sam Jerolim, časnik čiji je životopis središnji predmet ovog priloga. Djelujući, kako je već spomenuto, u pukovniji Paskvali od 1761. godine, posebno se istaknuo boraveći u Splitu i okolici u vrijeme kada je taj kraj zadesila kužna pohara. S obzirom na to da je u međuvremenu preminuo Jerolim Furioso, ${ }^{34}$ jedan od Paskvalijevih kapetana, ovom se dukalom Jerolim Smeća imenuje zapovjednikom satnije fù Capitano Gerolamo Furioso del Reggimento Colonnello Benetto Pasquali Pima di Fanti Nazionali. ${ }^{35}$

Prethodno izneseni podatci sadržani su u dukalama koje objavljuju generalni providuri Dalmacije. Brojne dodatne podatke o vojnoj službi Jerolima Smeće nalazimo $u$ popisima pojedinih satnija unutar pukovnija, pohranjenih $u$ središnjoj mletačkoj državnoj pismohrani. Ti nam dokumenti otkrivaju smjerove i odredišta Smećina djelovanja, ali i pružaju vrlo rječitu sliku o vojnom ljudstvu kojim je Jerolim osobno zapovijedao.

Najviše sačuvanih popisa Smećinih „ljudi pod oružjem“ sačuvano je iz šezdesetih i sedamdesetih godina 18. stoljeća, tj. iz vremena kada je Jerolim obnašao čin kapetana u pukovniji Benedikta Paskvalija. Prvi takav popis potječe iz 1765. godine (2. prosinac), a načinjen je u Mletcima, neposredno pred upućivanje Smećine jedinice prekomorskih pješaka u mjesto Salò na području Brescije ad obedienza Paolo Trevisan, provveditore e capitano di Salò. ${ }^{36}$ Jedinica Jerolima Smeće, sastavni dio pukovnije Paskvali koja je tada brojala ukupno šest satnija, imala je u svojem osnovnom sastavu čak 89 vojnika i dočasnika. U sklopu (do)časničkog kadra izrijekom se bilježe, uz kapetana Jerolima Smeću, još i zastavnik Petar Antun Cergna (Sergna), kadet (Jerolimov sin) Petar Viktor, narednici Pavao Grubišić i Petar Kovačević, kaplari Niko Vulov, Šime Marković, Marko Belin i Marko Mihalović te - kao obnašatelji posebnih službi - bubnjari Alvise Saulić i Jure Zvonarević. Uz navedene, u satniji se nalazilo i 78 običnih vojnika. Dio njih (15) je tijekom iste ili sljedeće godine prekrižen s popisa, najčešće radi prijelaza u drugu jedinicu, ali i radi dezertiranja ili smrti.

Upis osobnih podataka o Smećinim dočasnicima i vojnicima obavljen je na uobičajen način. Za većinu je navedeno - uz osobno ime i prezime - i ime oca, kao i mjesto podrijetla. ${ }^{37}$ Vojno ljudstvo Smećine satnije ponajprije su činili Dalmatinci

34 Vjerojatno je riječ o odvjetku obitelji Dešković Furioso, koja je svoje sjedište imala u Omišu.

35 HR-DAZD, GPDA, Pietro Michiel (1763. - 1765.), kut. 159, sv. I, fol. 163'-164 (Zadar, 25. VIII. 1764.).

36 ASV, Inquisitori ... pubblici ruoli, b. 671. Fanti Oltramarini: Reggimento Colonnello Benetto Pasquali (1750. - 1765.). Compagnia Capitano Gerolamo Smacchia.

37 Zavičajno podrijetlo najčešće nije navedeno za osobe koje obnašaju dočasnički čin. Vjerojatno je taj podatak bio unutar satnije svima općenito poznat te popisivači nisu smatrali da ga treba posebno navoditi. 
(56,18 \% od ukupnog broja vojnika). Najviše ih potječe s područja Kaštela te iz gradova Zadra i Splita, a nešto se većim brojem izdvajaju još i vojnici iz Cresa, Bibinja, Šibenika, Hvara i Skradina. Preostala mjesta, kako ona smještena na obali (Posedarje, Slivnica, Sukošan, Rogoznica, Trogir, Omiš, neretvansko područje), otocima (Pag, Kukljica na otoku Ugljanu, Dobropoljana na otoku Pašmanu, Jezera na otoku Murteru, Korčula) ili u zaleđu Dalmacije (Zemunik, Sinj, Vrgorac, Imotski), spomenuta su isključivo u pojedinačnim primjerima. Zastupljenost vojnika iz drugih krajeva znatno je manja, a zapaženiji postotni omjer odnosi se na one s područja crnogorskog priobalja (Risan, Stoliv, Luštica, Grbalj, Budva ukupno $15,73 \%$ ). S područja Istre (najčešće su navedeni samo općom regionalnom oznakom) potječe 8,99 \% vojnika u Compagnia Smacchia, iz Albanije dolazi 2,25 \%, a iz sjeverne Hrvatske (Lika) i Italije (Gorizia) samo po 1,12 \% vojnika. Naposljetku, za dio vojnika nije moguće utvrditi njihovo pobliže podrijetlo (nije navedeno $\mathrm{u}$ izvorima) te na njihov omjer u ukupnom izračunu iznosi 14,61 \% (Grafikon 1.).

Popisi vojnika u satniji kapetana Smeće bitnije se ne razlikuju i tijekom idućih godina te je - uz manje izmjene - sastav ljudstva prilično sličan popisu iz 1765. godine. Riječ je o popisima satnija iz pukovnije Benedikta Paskvalija, načinjenima 17. prosinca $1766 .,^{38} 7$. travnja $1767 .{ }^{39} 5$. lipnja $1767 .{ }^{40} 15$. prosinca $1771 .{ }^{41}$ i 16. siječnja 1772 . godine. ${ }^{42}$

38 Satnija je u svom osnovnom sastavu brojila 55 dočasnika i vojnika. Kao pričuvni kadet (Cadetto riformato) u Jerolimovoj satniji ponovno je naveden njegov sin Petar Viktor. Usporedi: ASV, Inquisitori ... pubblici ruoli, b. 672. Fanti Oltramarini: Reggimento Colonnello Benetto Pasquali (1765. - 1767.). Compagnia Capitano Gerolamo Smacchia.

39 Popis je načinjen u Mletcima, neposredno pred upućivanje satnije na službu u Udine. U satniji je zabilježen 71 dočasnik i vojnik. Neki od njih naknadno su prekriženi, a dodatno je dopisano još samo jedno ime. I u ovom popisu se kao kadet bilježi Petar Viktor Smeća. Usporedi: ASV, Inquisitori ... pubblici ruoli, b. 673. Fanti Oltramarini: Reggimento Colonnello Benetto Pasquali (1767. - 1769.). Compagnia Capitano Gerolamo Smacchia.

40 Satnija, popisana u Mletcima, u svojem je osnovnom sastavu brojila šezdeset ljudi. Naknadno su upisani još i: Josef Ivan iz Hrvatske, Ivan Mirković iz Zadra, Frane Kovačević iz Bakra, Ivan Petračević, Ivan Lončarić, Frane Lenardić i Antun Franić iz Istre, Ivan Krstitelj Plesić i Jere Valić $s$ austrijskog državnog područja (Imperial), Jure Poljak iz Solina, Jurić Prokolić iz Ugarske, Ivan Petrić iz Hvara, Vid Radulović iz Dalmacije te Dimitrije Bulli iz Albanije. Neki od navedenih vojnika također su naknadno prekriženi. U ovom se popisu Jerolimov sin Petar Viktor više ne navodi kao kadet. Usporedi: ASV, Inquisitori ... pubblici ruoli, b. 674. Fanti Oltramarini: Reggimento Colonnello Benetto Pasquali (1770. - 1771.). Compagnia Capitano Gerolamo Smacchia.

41 Satnija je popisana na Krfu, a broj vojnika je smanjen na 45. Usporedi: ASV, Inquisitori ... pubblici ruoli, b. 674. Fanti Oltramarini: Reggimento Colonnello Benetto Pasquali (1770. - 1771.). Compagnia Capitano Gerolamo Smacchia.

42 Satnija je popisana u Mletcima. Brojila je 52 dočasnika i časnika. Usporedi: ASV, Inquisitori ... pubblici ruoli, b. 675. Fanti Oltramarini: Reggimento Colonnello Benetto Pasquali (1772. - 1774.). Compagnia Capitano Gerolamo Smacchia. 


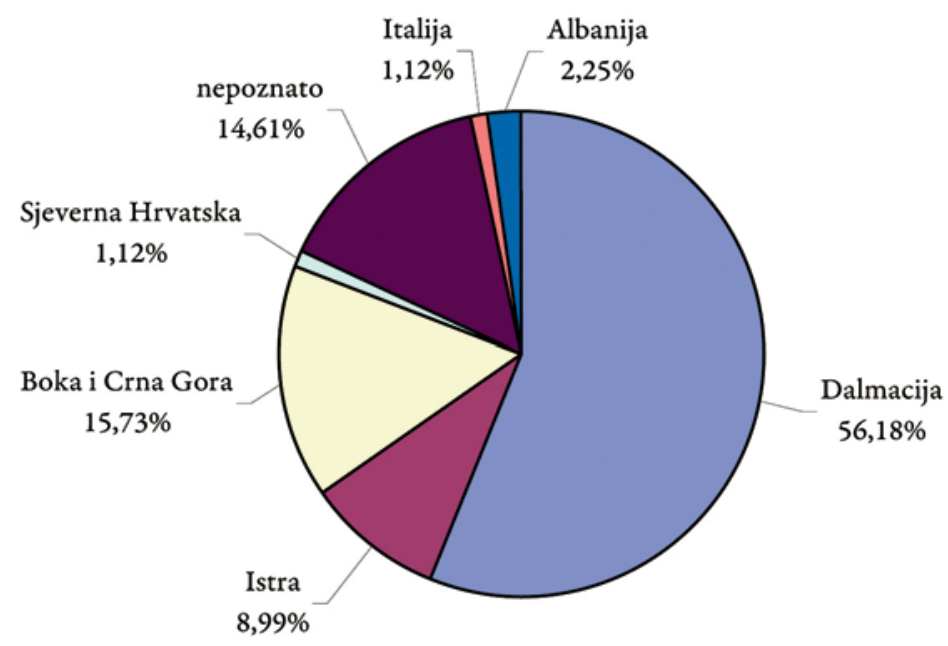

GRAFIKON 1. Zavičajna struktura ukupnog vojnog ljudstva Smećine satnije prema popisu iz 1765. godine

Za ovo istraživanje zanimljiv je - kao usporedba između prvog i posljednjeg popisa Smećinih vojnika u vrijeme njihove uključenosti u pukovniju Paskvali popis nastao 16. veljače 1773 . u Udinama. ${ }^{43} \mathrm{U}$ prvom dijelu popisa, kako je to uobičajeno, navode se - uz kapetana Smeću - dočasnici te obnašatelji posebnih službi u satniji. Redom su zabilježeni zastavnik Anđelo Marija Antivari, narednici Pavao Grubišić i Niko Vulov (potonji je iz Crne Gore), kaplari Šime Marković, Ivan Talajić iz Imotskog, Ivan Crivier iz Kaštela i Petar Siderić iz Like, dok se kao bubnjari spominju Petar Saulić i Karlo Bonaventura iz Zadra. Uz spomenute dočasnike i bubnjare, u satniji se isprva nalazilo još četrdeset običnih vojnika, ali je dio njih tijekom 1773. godine prekrižen (ukupno ih je prekriženo devet). Na njihovo mjesto privremeno su (i dio njih je naknadno prekrižen) pridodana još trojica bubnjara (Dominik Brevini iz Šibenika te Ivan Ivanišević i Danijel Ivanović iz Crne Gore), kao i 12 običnih vojnika. Za manji dio Smećinih vojnika iz 1773. godine napisana je i njihova dob. Uz nekoliko primjera pripadnika satnije

43 Usporedi: ASV, Inquisitori ... pubblici ruoli, b. 675. Fanti Oltramarini: Reggimento Colonnello Benetto Pasquali (1772. - 1774.). Compagnia Capitano Gerolamo Smacchia. 


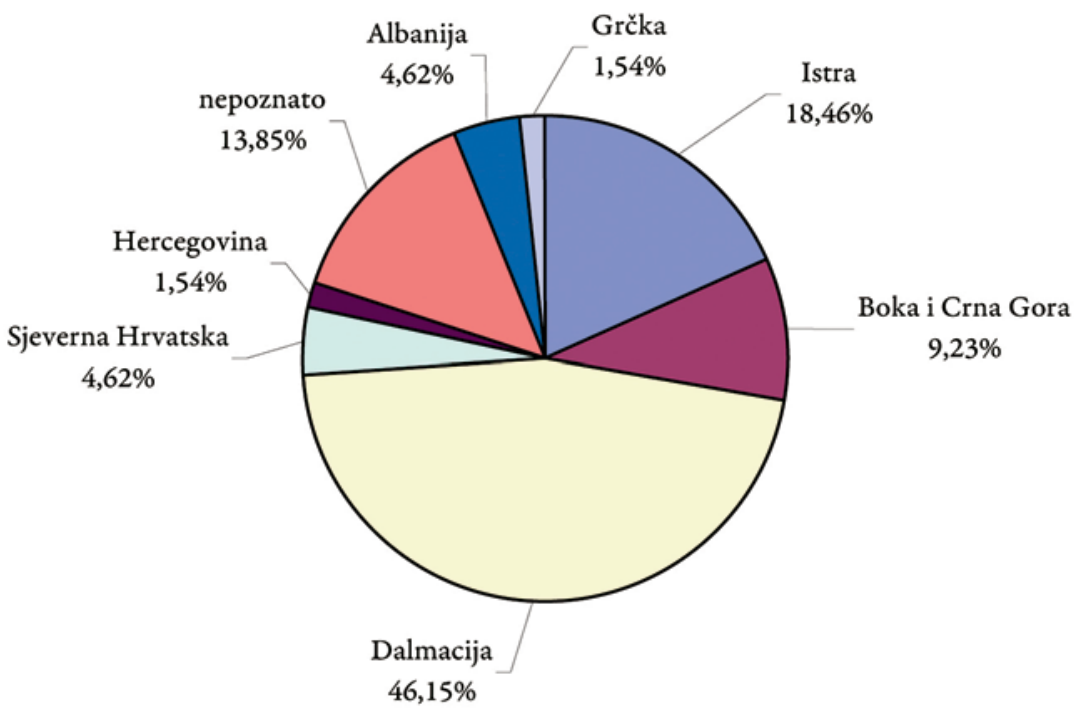

GRAFI KON 2. Zavičajna struktura ukupnog vojnog ljudstva Smećine satnije prema popisu iz 1773. godine

u dječačkoj dobi (bubnjari), većina vojnika stara je između dvadeset i trideset godina, a prosjek godina iznosi 22.

Zavičajna struktura dočasnika i vojnika i u ovom slučaju, kao i u prethodnim primjerima, pokazuje prevagu Dalmatinaca (46,15\%). I ovdje je cijeli niz manjih dalmatinskih mjesta iz kojih potječu jedan ili dva vojnika (Cres, Posedarje, Biograd na Moru, Pašman, Vodice, Bristivica kraj Trogira, Brač, Cetina, Omiš, Vrgorac, Imotski i druga), a nešto se većim brojem primjera spominju vojnici iz Kaštela, Zadra i Šibenika. Zapažen broj vojnika potječe iz Istre (18,46 \%), a kao konkretna mjesta njihova zavičaja navode se Pula, Ližnjan i Novigrad. Iz unutrašnjosti Crne Gore te iz Risna i Bara dolazilo je 9,23 \% vojnika djelatnih u ovoj satniji, dočim je na vojnike iz sjeverne Hrvatske (Rijeka, Lika), kao i na Albance, otpadalo po 4,62 \%. U pojedinačnim se primjerima (po 1,54\%) bilježe i vojnici iz Hercegovine (Mostar) i Grčke (Peloponez). Naposljetku, na vojnike čije podrijetlo jest nedvojbeno slavensko, ali za koje nismo u mogućnosti precizno odrediti njihov zavičaj, otpada $13,85 \%$ od ukupnog broja vojnika (Grafikon 2). 
Tijekom druge polovice sedamdesetih i početkom osamdesetih godina 18. stoljeća Jerolim Smeća bilježi se - ovog puta u činu bojnika (Sargente maggiore) u pukovniji Nikole Scutarija. ${ }^{44}$ Smećina je jedinica prekomorskih pješaka tada bila stacionirana (te tako i popisana) na području mletačke terraferme (u Bresciji 1. rujna 1777.), u Mletcima (1. ožujka 1778.), na otoku Krfu (29. veljače 1780. i 31. kolovoza 1780.) te u Kotoru (1. ožujka 1783.). ${ }^{45}$ Popisi su, s obzirom na sastav ljudstva, prilično ujednačeni te ćemo se u raščlambi ukratko pozabaviti samo završnim popisom, načinjenim u Kotoru 1783. godine. Smećina je satnija tada brojila četrdeset ljudi, među kojima se u svojstvu dočasnika i obnašatelja posebnih službi bilježe kadeti Josip Antun Sikirić i Mihovil Nakić, narednici Pavao Grubišić i Ivan Krivić, kaplari Ante Ivanović i Ivan Jovišić, bubnjari Santo Ivanović i Ivan Ferabilić te pifarist (Piffaro) Antun Krivić. U ovoj etapi vojne karijere Jerolima Smeće njegova je postrojba djelovala kao mornaričko pješaštvo. Stoga kao mjesto njihova trenutnog boravka nisu zabilježene gradske utvrde, već vojni brodovi (stacionirani na Rive di Cattaro), ponajprije galera capitania (zapovjedni brod) te - u nevelikom broju primjera - manji brodići (šambek) nekih drugih ondje prisutnih časnika. Nažalost, u ovom popisu nije zabilježeno zavičajno podrijetlo dočasnika i vojnika. Međutim, na osnovu navedenih prezimena možemo sasvim pouzdano zaključiti kako je riječ o vojnicima zavičajem sa šireg područja istočnog Jadrana, ponajprije iz Dalmacije i Boke.

\section{NAJVIŠI POSTIGNUTI ČIN: SAMOSTALNA PUKOVNIJA JEROLIMA SMEĆE}

Tijekom idućih desetak godina nisu nam poznati (sačuvani) popisi postrojbi kojima je osobno zapovijedao Jerolim Smeća. Sljedeći sačuvani podatci datiraju od 1794. do 1797. godine i odnose se na djelovanje Smeće u činu pukovnika. U navedenom je razdoblju u Smećinoj pukovniji djelovalo, ovisno o pojedinoj godini, pet ili šest satnija kojima su (uz satniju kojom je osobno zapovijedao Jerolim Smeća) upravljali kapetan i conte Petar Alačević (1794. - 1796.), kapetan

44 Nikola Scutari bilježi se kao pukovnik prekomorske pješačke postrojbe od 1772. do 1793. godine. Usporedi gradivo u ASV, Inquisitori ... pubblici ruoli, b. 643, 697-701 (Fanti Oltramarini). Prema podatcima iz Scutarijeve oporuke, napisane u Zadru 1797. godine, taj je visoki mletački časnik iako prezime upućuje na albansko podrijetlo (Skadar) - zavičajem iz Starog Grada na otoku Hvaru. Usp.: HR-DAZD, Spisi zadarskih bilježnika: Domenico Castelli (1777. - 1812.), b. 37, filza III, br. 99, 18. III. 1797.

45 ASV, Inquisitori ... pubblici ruoli, b. 643. Fanti Oltramarini: Reggimento Colonnello Nicolò Scutari. Compagnie Sargente maggiore Gerolamo Smacchia. 


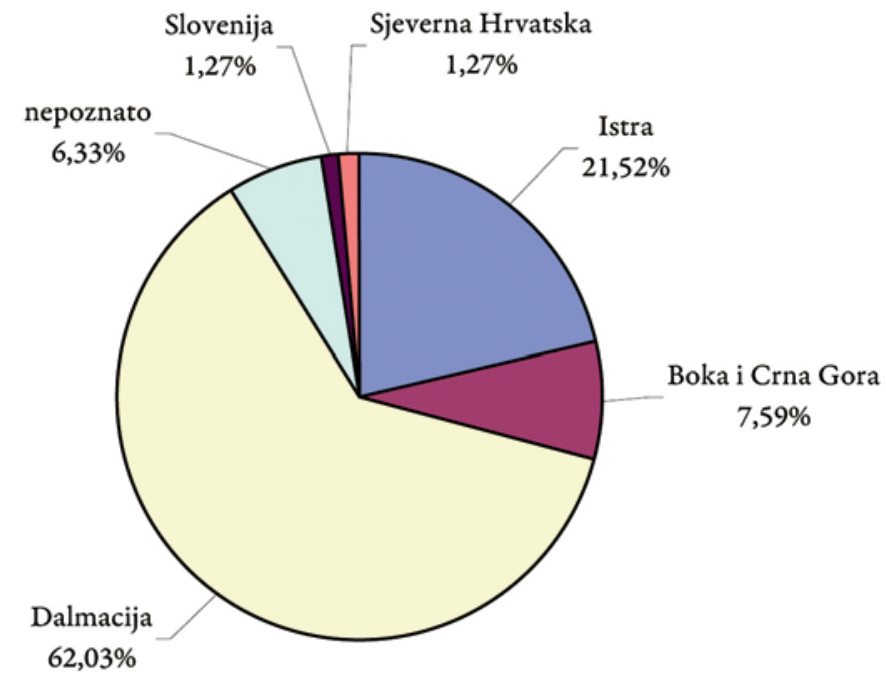

GRAFI KON 3. Zavičajna struktura ukupnog vojnog ljudstva Smećine satnije prema popisu iz 1794. godine

Ivan Barbarić (1796.), potpukovnik Ivan Paravia (1796.), kapetan Josip Arvatini (1797.) i kapetan Nikola Paštrović (1796.). ${ }^{46}$

Sačuvan nam je i popis vojnog ljudstva iz compagnia propria Jerolima Smeće. Popis je načinjen u Mletcima 12. kolovoza 1794., neposredno uoči upućivanja jedinice na vojnu dužnost u Bresciju. Dočasnički kadar činili su tada zastavnik Petar Kaletić, kadet Petar Milošević, narednici Frane Gerdum iz Petrovog polja (drniško područje) i Filip Kobelica iz Selina kraj Zadra, kaplari Ivan Cvitak iz Istre, Dujam Filipović iz Dalmatinske zagore, Stipe Oliverić iz Crne Gore i Grgur Obrvan s neretvanskog područja, a satniji su bili pridodani i bubnjar Donat Gambirasi iz Knina i pifarist - Donatov brat Dominik Gambirasi. Uz navedene dočasnike, u satniji je 1794. godine djelovalo još 68 običnih vojnika, od kojih je tijekom iste te sljedeće godine prekriženo njih sedam, a zanimljivo je da satniji naknadno nije pridodan nijedan novi vojnik ili dočasnik.

Istraživačke su pozornosti vrijedni podatci o zavičajnoj strukturi Smećinih vojnika na samom kraju 18. stoljeća (Grafikon 3.). I ovdje prevagu imaju Dalmatinci (62,03\%), a unutar dalmatinske skupine vojnika prednjače Neretvani

46 ASV, Inquisitori ... pubblici ruoli, b. 702. Fanti Oltramarini: Reggimento Colonnello Gerolamo Smacchia (1794. - 1797.). 
(Narenta) te njihov postotni udio u dalmatinskom korpusu Smećina ljudstva iznosi čak 40,82 \%, a u ukupnom omjeru također zapaženih $25,32 \%$. Brojčanim udjelom još se izdvajaju i Kninjani, dočim su druga dalmatinska mjesta ili krajevi navedeni kao matični zavičaj ovih vojnika zabilježeni u jedan do dva primjera. Opaža se značajan udio vojnika iz manjih mjesta u zaleđu Dalmacije (Kula Atlagića, Islam, Žegar, Vrana, Drniš, Petrovo polje) odnosno iz obalnog dijela i s otoka (Savar, Seline, Primošten, Rogoznica, Kaštela), dočim su kao važnija zavičajna gradska naselja zabilježeni Zadar, Šibenik, Trogir i Split. Zapažen je, kao i u prethodnim primjerima, i udio Smećinih vojnika iz Istre (21,52\%). Uz opću odrednicu (Istria / Istrian), kao konkretna mjesta njihova podrijetla navode se još i grad Poreč te malo naselje Sovinjak, čiji vojnici imaju čak 52,94 \% udjela u ljudstvu te mletačke pokrajine (u ukupnom omjeru svih Smećinih vojnika iz 1794. godine vojnici iz Sovinjaka čine 11,39 \%). S područja unutrašnjosti Crne Gore te iz Boke dolazi 7,59\% vojnika, a izrijekom se kao konkretno mjesto zavičaja bilježi samo grad Kotor. U pojedinačnim se primjerima spominju i vojnici s hrvatskog dijela pod habsburškom vlašću (Lika) te iz današnje Slovenije (Kranjska), a njihov je udio brojčano neznatan (po 1,27 \%). Naposljetku, za manji dio ovdje popisanih Smećinih vojnika nije moguće utvrditi točnije zavičajno podrijetlo te njihov ukupan omjer iznosi $6,33 \%{ }^{47}$

\section{ZAKLJUČNI OSVRT}

Popis iz 1794. godine završni je dokument iz zbirke Inquisitori sopra l'amministrazione dei pubblici ruoli koji se odnosi na pukovnika Jerolima Smeću. Samo tri godine poslije Mletačka je Republika trajno sišla s povijesne pozornice. Fanti Oltramarini, Croati a cavallo i druge mletačke prekomorske postrojbe prestale su postojati, a nekadašnji časnici u službi Serenissime svoju su vojnu karijeru prekinuli umirovljenjem ili su - osobito u doba austrijske uprave - svoj vojni poziv nastavili djelujući pod drugim državnim stijegom. Što se dogodilo i koja je bila sudbina Jerolima Smeće ne možemo pouzdano utvrditi na osnovu postojećih podataka. U godini pada Mletačke Republike Smeća je zasigurno imao oko 75 godina (uzevši u obzir pretpostavku da je 1740. godine

47 Ovdje je potrebno napomenuti da se velik udio vojnika s područja Neretve (Neretvanska krajina), Knina i sela Sovinjak u Istri može tumačiti priključivanjem snaga teritorijalne milicije (cernide, teritorijalci) profesionalnim postrojbama. Takve primjere učestalo bilježimo na samom kraju stoljeća, kada Mletačka Republika po posljednji puta mobilizira znatnije vojno ljudstvo, a velik dio tih postrojbi činili su Dalmatinci, Istrani i Bokelji. 
postao kadet, a tada je vjerojatno imao 17 ili 18 godina) te je najvjerojatnije bio umirovljen. Zasigurno će neka buduća istraživanja, ponajprije zasnovana na radu u kotorskim pismohranama, donijeti neke nove podatke o završnoj etapi Smećina života i djelovanja. Ovaj rad, koji usred nedostatka gradiva ne teži cjelovitosti, nastoji ukazati na jednog danas manje poznatog, ali značajem u doba svoga djelovanja vrlo istaknutog mletačkog vojnog časnika zavičajem iz Boke. Stoga je cilj ovoga, kao i budućih istraživanja gradiva iz mletačkog Državnog arhiva i Državnog arhiva u Zadru, znanstvenoj javnosti predstaviti još cijeli niz vojnih zaslužnika u doba Serenissime, a o čijim životopisima, vojnom djelovanju i priznatosti znamo vrlo malo. 
Prilog 1. Popis časnika, dočasnika i vojnika iz satnije kapetana Jerolima Smeće (Archivio di Stato di Venezia, Inquisitori sopra l'amministrazione dei pubblici ruoli, b. 671. Fanti Oltramarini: Reggimento Colonnello Benetto Pasquali. Compagnia Capitano Gerolamo Smacchia; Mleci, 2. XII. 1765.). ${ }^{48}$

\begin{tabular}{|l|l|}
\hline $\begin{array}{l}\text { 1. Kapetan (Capitano): Jerolim Smeća } \\
\text { (Smachia) }\end{array}$ & $\begin{array}{l}\text { 2. Zastavnik (Alfier): Pietro Antonio Cergna } \\
\text { (Sergna) }\end{array}$ \\
\hline 3. Kadet (Cadetto): Petar Viktor Smeća & $\begin{array}{l}\text { 49 Narednik (Sargente): Pavao Grubišić - } \\
\text { Jure }\end{array}$ \\
\hline 5. Narednik (Sargente): Petar Kovačević & $\begin{array}{l}\text { 6. Kaplar (Caporal): Niko Vulov - Vule - } \\
\text { Crna Gora }\end{array}$ \\
\hline 7. Kaplar (Caporal): Šime Marković - Šime & 8. Kaplar (Caporal): Marko Belin - Šime \\
\hline 9. Kaplar (Caporal): Marko Mihalović & $\begin{array}{l}\text { 10. Bubnjar (Tamburo): Alvise Saulić - } \\
\text { Krstitelj - dječak (putto) }\end{array}$ \\
\hline $\begin{array}{l}\text { 11. Bubnjar (Tamburo): Jure Zvonarević - } \\
\text { Jure - Cres }\end{array}$ & \\
\hline
\end{tabular}

Vojnici (Soldati):

\begin{tabular}{|l|l|}
\hline 12. Ivan Usatić - Juraj - Hvar & 13. Ivan Gonar - Krile - Istra \\
\hline 14. Ivan Saulić - Mate & 15. Ivan Funasović - Andrija - Rovinj \\
\hline 16. Jure Pusić - Andrija - Istra & 17. Ivan Mišetić - Šimun - Jezera \\
\hline 18. Ivan Talajić - Jure - Imotski & 19. Ivan Mandić - Ilija - Sinj \\
\hline 20. Mihovil Barković - Matija - Istra & 21. Anastazije Barković - Mate - Istra \\
\hline 22. Luka Maroević - Petar - Kaštela & 23. Miho Napoli/Sdopeli - Mate - Omiš \\
\hline 24. Ante Blažević - Mate - Istra & 25. Jure Sušić - Ive - Cres \\
\hline 26. Antun Josić - Andrija - Cres (prekrižen) & 27. Jovo Lazović - Jovo - Risan (prekrižen) \\
\hline 28. Pavo Đukanović - Jakov - Crna Gora & 29. Ivan Vujov - Vujo - Crna Gora \\
\hline 30. Pero Lazari - Lazo (prekrižen) & 31. Ivan Markov - Marko - Stoliv \\
\hline 32. Rade Petrov - Jovo - Luštica & 33. Špiro Jukov - Mate - Risan \\
\hline 34. Mate Milić - Grgo - Istra & 35. Stanko Marinović - Vuko - Crna Gora \\
\hline 36. Nikola Jovov - Niko - Grbalj & $\begin{array}{l}\text { 37. Stipan Adumov - Tonko - Šibenik } \\
\text { (prekrižen) }\end{array}$ \\
\hline 38. Petar Aleksić - Marko - Dobropoljana & 39. Stipan Gerović - Šimun - Budva \\
\hline 40. Antun Komšija - Martin - Posedarje & 41. Antun Remitić - Ivan - Zemunik \\
\hline 42. Josip Manestrić - Gaetan - Split & 43. Josip Pisetić - Ante - Split \\
\hline 44. Stjepan Klarić - Lovre - Istra & 45. Petar - Juraj - Albanija \\
\hline
\end{tabular}

48 Popisi časnika, dočasnika i vojnika u svim postrojbama oltramarina, te tako i u primjeru satnije kojom je zapovijedao Jerolim Smeća, pisani su jednoobrazno. Najprije se bilježi zapovjednik satnije, zatim ostali časnici i dočasnici te potom obični vojnici. Uz njihova imena i prezimena navodi se i ime oca te njihovo zavičajno podrijetlo.

49 Dopisano: figlio di Capitano. 


\begin{tabular}{|c|c|}
\hline 46. Dume Cvitković - Mate - Split & 47. Mijat Milinković - Pavao (prekrižen) \\
\hline 48. Filip Velić - Ilija - Skradin (prekrižen) & 49. Šime Smolić - Mate - Sukošan \\
\hline 50. Frane Morović - Josip - Korčula & 51. Antun Antonelić - Gaetan - Zadar \\
\hline 52. Antun Tomašić - Filip - Zadar & 53. Vukota - Vukov - Vuko - Crna Gora \\
\hline $\begin{array}{l}\text { 54. Duje Vidović - Nikola - Šibenik } \\
\text { (prekrižen) }\end{array}$ & 55. Toma Petrov - Ivan (prekrižen) \\
\hline 56. Bare Barić - Ivan - Slivnica (Posedarje) & 57. Šime Karlić - Mate - Kukljica \\
\hline 58. Jure Sarić - Nikola - Lika & 59. Petar Marušić - Petar - Trogir \\
\hline 60. Jakov Brajković - Josip - Skradin & 61. Juraj Starić - Grgur - Zadar (prekrižen) \\
\hline 62. Grgo Partanica - Andrija - Neretva & 63. Jovo Ljubanović - Juro - Grbalj \\
\hline 64. Mate Rotić - Luka - Pag & 65. Bože Erljić - Filip - Skradin - 22 \\
\hline 66. Andrija Franić - Frane - Kaštela - 25 & 67. Jure Jurašinović - Bože - Kaštela \\
\hline 68. Ivan Crivier - Ive - Kaštela & 69. Frane Pavlović - Matija - Split \\
\hline 70. Mate Ercegović - Blaž - Rogoznica - 23 & 71. Vicko Batarinov - Toma - Kaštela - 17 \\
\hline 72. Jadre Jadrinović - Ivan - Vrgorac & $\begin{array}{l}\text { 73. Josip Šindija - Ive - Bibinje - } 20 \\
\text { (prekrižen radi dezertiranja) }\end{array}$ \\
\hline $\begin{array}{l}\text { 74. Ante Delić - Grgo - Bibinje - } 20 \\
\text { (prekrižen; preminuo 5. veljače 1766.) }\end{array}$ & 75. Ivan Petrić - Petar - Hvar - 16 \\
\hline $\begin{array}{l}\text { 76. Jakov Klarić - Nikola - Hvar - } 24 \\
\text { (prekrižen; preminuo 17. lipnja 1766.) }\end{array}$ & 77. Nikola Gazija - Ivan - Šibenik - 26 \\
\hline $\begin{array}{l}\text { 78. Jure Radošević - Nikola - Gorizia - } 20 \\
\text { (prekrižen) }\end{array}$ & 79. Toma Vuletić - Ivan - 17 \\
\hline 80. Miho Valčić - Ive - Cres - 20 & 81. Vicko Smoković - Andrija - Split - 20 \\
\hline $\begin{array}{l}\text { 82. Ivan Tonišić - Šime - Bibinje - } 25 \\
\text { (prekrižen radi dezertiranja) }\end{array}$ & 83. Nikola Petri - Petar - Albanija - 18 \\
\hline $\begin{array}{l}\text { 84. Jure Gipin - Antun - Kaštela - } 21 \\
\text { (prekrižen) }\end{array}$ & 85. Antun Dunin - Bože - Kaštela - 20 \\
\hline 86. Josip Dominis - Toma - Zadar - 19 & 87. Krstitelj Mirkov - Pave - Kaštel Lukšić \\
\hline 88. Bože Kusinović - Pere - Zadar - 28 & 89. Mihovil Battara - Andrija - Zadar \\
\hline
\end{tabular}


Prilog 2. Popis časnika, dočasnika i vojnika iz satnije kapetana Jerolima Smeće (Archivio di Stato di Venezia, Inquisitori sopra l'amministrazione dei pubblici ruoli, b. 675. Fanti Oltramarini: Reggimento Colonnello Benetto Pasquali. Compagnia Capitano Gerolamo Smacchia; Udine, 16. II. 1773.).

\begin{tabular}{|l|l|}
\hline $\begin{array}{l}\text { 1. Kapetan (Capitano): Jerolim Smeća } \\
\text { (Smacchia) }\end{array}$ & $\begin{array}{l}\text { 2. Zastavnik (Alfier): Anđelo Marija } \\
\text { Antivari }^{50}\end{array}$ \\
\hline $\begin{array}{l}\text { 3. Narednik (Sargente): Pavao Grubišić - } \\
\text { Jure }\end{array}$ & $\begin{array}{l}\text { 4. Narednik (Sargente): Niko Vulov - Vule - } \\
\text { Crna Gora }\end{array}$ \\
\hline 5. Kaplar (Caporal): Šime Marković - Šime & $\begin{array}{l}\text { 6. Kaplar (Caporal): Ivan Talajić - Jure - } \\
\text { Imotski }\end{array}$ \\
\hline $\begin{array}{l}\text { 7. Kaplar (Caporal): Ivan Crivier - Ive - } \\
\text { Kaštela }\end{array}$ & $\begin{array}{l}\text { 8. Kaplar (Caporal): Petar Siderić - Lazo - } \\
\text { Lika }\end{array}$ \\
\hline $\begin{array}{l}\text { 9. Bubnjar (Tamburo): Petar Saulić - } \\
\text { Krstitelj - dječak (putto) }\end{array}$ & $\begin{array}{l}\text { 10. Bubnjar (Tamburo): Karlo - } \\
\text { Bonaventura - Antun - Zadar - 14 } \\
\text { (prekrižen) }\end{array}$ \\
\hline
\end{tabular}

Vojnici (Soldati):

\begin{tabular}{|l|l|}
\hline 11. Marko Vlastelica - Josip - Zagora & 12. Alvise Saulić - Krstitelj \\
\hline 13. Jure Pusić - Andrija - Istra & 14. Josip Saulić - Mate \\
\hline 15. Ivan Sušić - Ive - Cres & 16. Špiro Jukov - Mate - Risan \\
\hline 17. Miho Napoli/Sdopeli - Mate - Omiš & 18. Antun Komšija - Martin - Posedarje \\
\hline 19. Stjepan Klarić - Lovro - Istra & 20. Petar - Juraj - Albanija \\
\hline 21. Jadre Jadrinović - Ivan - Vrgorac & 22. Miho Valčić - Ive - Cres \\
\hline $\begin{array}{l}\text { 23. Bože Grgurica - Bare - Kaštel Lukšić } \\
\text { prekrižen) }\end{array}$ & 24. Nikola Vitanović - Šime \\
\hline $\begin{array}{l}\text { 25. Mate Ivanović - Šime - Albanija } \\
\text { 27. Drago Vukov - Vuko }\end{array}$ & $\begin{array}{l}\text { 26. Petar Zanzić - Bože - Dalmacija } \\
\text { (prekrižen) }\end{array}$ \\
\hline 29. Dume Cvitković - Mate - Split & 28. Mate Matičević - Jure - Lika \\
\hline 31. Antun Degović - Jure - Ližnjan & 30. Petar Degović - Jure - Ližnjan \\
\hline $\begin{array}{l}\text { 33. Petar Baričević - Marko - Bristivica } \\
\text { (Trogir) }\end{array}$ & 32. Vido Bersatić - Grgo - Istra \\
\hline $\begin{array}{l}\text { 35. Antun Ivić - Nikola - Kaštela } \\
\text { (prekrižen) }\end{array}$ & $\begin{array}{l}\text { 36. Ivan Mirković - Pave - Zadar } \\
\text { (prekrižen) }\end{array}$ \\
\hline 37. Ivan Pervić - Petar - Cetina & 38. Vid Radulović - Pantelija - Dalmacija \\
\hline $\begin{array}{l}\text { 39. Dimitri Dule - Stjepan - Albanija } \\
\text { (prekrižen) }\end{array}$ & 40. Antun Sladović - Jakov - Vodice \\
\hline $\begin{array}{l}\text { 41. Nikola Marinović - Frane - Šibenik } \\
\text { prekrižen) }\end{array}$ & $\begin{array}{l}\text { 42. Antun Posaković - Andrija - Peloponez } \\
\text { (prekrižen) }\end{array}$ \\
\hline
\end{tabular}




\begin{tabular}{|l|l|}
\hline 43. Antun Garagnini - Petar - Dalmacija & $\begin{array}{l}\text { 44. Josip Musacho - Stipe - Zadar } \\
\text { (prekrižen) }\end{array}$ \\
\hline 45. Ambroz Lulić - Toma - Biograd - 25 & 46. Božo Scride - Andrija - Istra - 20 \\
\hline 47. Antun Marinović - Martin - Istra - 18 & 48. Šime Ivanišević \\
\hline 49. Petar Cesanović & 50. Ivan Jurišić - Ivan - Rijeka \\
\hline
\end{tabular}

Naknadno dopisani:

\begin{tabular}{|l|l|}
\hline $\begin{array}{l}\text { 1. Bubnjar (Tamburo): Dominik Brevini - } \\
\text { Anđelo - Šibenik - 17 (prekrižen) }\end{array}$ & $\begin{array}{l}\text { 2. Bubnjar (Tamburo): Ivan Ivanišević - } \\
\text { Sime - Crna Gora - 15 }\end{array}$ \\
\hline $\begin{array}{l}\text { 3. Bubnjar (Tamburo): Danijel Ivanović - } \\
\text { Nikola - Crna Gora - 11 }\end{array}$ & 4. Ivan Ivanković - Ivan - Rab - 30 \\
\hline $\begin{array}{l}\text { 5. Ante Marmara - Nikola - Šibenik - 35 } \\
\text { 7. Petar Luković - Petar - Brač - 24 } \\
\text { (prekrižen) }\end{array}$ & $\begin{array}{l}\text { 6. Valentin Bascia - Josip - Split - 18 } \\
\text { prekrižen) }\end{array}$ \\
\hline $\begin{array}{l}\text { 9. Jadre Erbošić - Mate - Pašman - 29 } \\
\text { 11. Jerolim Lombardo - Nikola - Pula - 20 }\end{array}$ & $\begin{array}{l}\text { 10. Jakov Ostojić - Jadre - Novigrad } \\
\text { Istarski - 19 }\end{array}$ \\
\hline 13. Krsto Munarić - Luka - Istra - 19 & 14. Jakov Tisović - Istra - 38 \\
\hline 15. Frane Perićev - Ivan - Hvar & \\
\hline
\end{tabular}


Prilog 3. Popis časnika, dočasnika i vojnika iz satnije bojnika Jerolima Smeće (Archivio di Stato di Venezia, Inquisitori sopra l’amministrazione dei pubblici ruoli, b. 643. Fanti Oltramarini: Reggimento Colonnello Nicolò Scutari. Compagnia Sargente maggiore Gerolamo Smacchia; Kotor, 1. III. 1783.).

\begin{tabular}{|l|l|}
\hline 1. Bojnik (Sargente maggiore): Jerolim Smeća & 2. Kadet (Cadetto): Josip Antun Sikirić \\
\hline 3. Kadet (Cadetto): Mihovil Nakić & $\begin{array}{l}\text { 4. Narednik (Sargente): Pavao Grubišić } \\
\text { (galera capitania) }\end{array}$ \\
\hline $\begin{array}{l}\text { 5. Narednik (Sargente): Ivan Krivić } \\
\text { (sciamboco Alfier Barbarich) }\end{array}$ & $\begin{array}{l}\text { 6. Kaplar (Caporal): Ante Ivanović (galera } \\
\text { capitania) }\end{array}$ \\
\hline $\begin{array}{l}\text { 7. Kaplar (Caporal): Ivan Jovišić (galera } \\
\text { capitania) }\end{array}$ & $\begin{array}{l}\text { 8. Bubnjar (Tamburo): Santo Ivanović } \\
\text { (galera capitania) }\end{array}$ \\
\hline $\begin{array}{l}\text { 9. Bubnjar (Tamburo): Ivan Ferabilić (galera } \\
\text { capitania) }\end{array}$ & $\begin{array}{l}\text { 10. Pifarist (Piffaro): Antun Krivić } \\
\text { (sciamboco Alfier Barbarich) }\end{array}$ \\
\hline
\end{tabular}

Vojnici (Soldati):

\begin{tabular}{|c|c|}
\hline 11. Miho Jukšić (Giuxich) (galera capitania) & 12. Šime Sutić (galera capitania) \\
\hline 13. Grgo Barišić (galera capitania) & 14. Miho Điković (galera capitania) \\
\hline 15. Luka Knežević (galera capitania) & 16. Antun Kombrić (galera capitania) \\
\hline 17. Ilija Ravlić (galera capitania) & 18. Andrija Petrović (all'ospedale di Cattaro) \\
\hline 19. Ive Krivić (galera capitania) & $\begin{array}{l}\text { 20. Paško Bartulović (camerota del Sargente } \\
\text { maggiore) }\end{array}$ \\
\hline 21. Antun Salvadori (galera capitania) & $\begin{array}{l}\text { 22. Toma Rasto (sciamboco Sargente } \\
\text { Vicarovich) }\end{array}$ \\
\hline 23. Petar Topić (galera capitania) & 24. Miloš Jović (galera capitania) \\
\hline 25. Bano Ivanović (galera capitania) & $\begin{array}{l}\text { 26. Aleksandar Sablić (camerota del Sargente } \\
\text { maggiore) }\end{array}$ \\
\hline 27. Pere Sablić (filuca sargente Luca) & $\begin{array}{l}\text { 28. Jerko Ivičević (sciamboco Sargente } \\
\text { Vicarovich) }\end{array}$ \\
\hline 29. Ante Tuzarović (galera capitania) & 30. Petar Belaja (galera capitania) \\
\hline 31. Jerolim Kunišić (galera capitania) & 32. Petar Ferabilić (galera capitania) \\
\hline 33. Ivan Giovanelli (galera capitania) & 34. Stjepan Ljubojević (galera capitania) \\
\hline 35. Frane Jurišić (galera capitania) & 36. Jure Botić (galera capitania) \\
\hline 37. Mate Pribičević (galera capitania) & 38. Grgur Burnović (galera capitania) \\
\hline 39. Nikola Martinović (galera capitania) & 40. Paško Gilević (all'ospedale di Mula) ${ }^{51}$ \\
\hline
\end{tabular}

51 Prema podacima iz Matične knjige umrlih župe sv. Tripuna u Kotoru vojnik Paško Gilević (u matici naveden kao Gijević), zavičajem iz Makarske, preminuo je 2. ožujka iste godine. Usp.: BAK, Matične knjige katedrale sv. Tripuna, Matična knjiga umrlih III (1775. - 1823.). 
Prilog 4. Popis časnika, dočasnika i vojnika iz osobne satnije pukovnika Jerolima Smeće (Archivio di Stato di Venezia, Inquisitori sopra l'amministrazione dei pubblici ruoli, b. 702. Fanti Oltramarini: Reggimento Colonnello Gerolamo Smacchia. Compagnia propria Colonnello Gerolamo Smacchia; Mleci, 12. VIII. 1794.).

\begin{tabular}{|l|l|}
\hline $\begin{array}{l}\text { 1. Pukovnik (Colonnello): Conte Jerolim } \\
\text { Smeća }\end{array}$ & 2. Zastavnik (Alfier): Petar Kaletić \\
\hline 3. Kadet (Cadetto): Petar Milošević - Ivan & $\begin{array}{l}\text { 4. Narednik (Sargente): Frane Gerdum - } \\
\text { Vid - Petrovo polje }\end{array}$ \\
\hline $\begin{array}{l}\text { 5. Narednik (Sargente): Filip Kobelica - } \\
\text { Josip - Seline (kraj Zadra) }\end{array}$ & $\begin{array}{l}\text { 6. Kaplar (Caporal): Ivan Cvitak - Frane - } \\
\text { Istra }\end{array}$ \\
\hline $\begin{array}{l}\text { 7. Kaplar (Caporal): Dujam Filipović - } \\
\text { Antun - Zagora }\end{array}$ & $\begin{array}{l}\text { 8. Kaplar (Caporal): Stipe Oliverić - Mijo - } \\
\text { Crna Gora }\end{array}$ \\
\hline $\begin{array}{l}\text { 9. Kaplar (Caporal): Grgur Obrvan - Luka - } \\
\text { Neretva }\end{array}$ & $\begin{array}{l}\text { 10. Bubnjar (Tamburo): Donat Gambirasi - } \\
\text { Ivan - Knin }\end{array}$ \\
\hline $\begin{array}{l}\text { 11. Pifarist (Piffaro): Dominik Gambirasi - } \\
\text { Ivan - Knin }\end{array}$ & \\
\hline
\end{tabular}

Vojnici (Soldati):

\begin{tabular}{|l|l|}
\hline 12. Joso Franić - Ivan - Zulinich? & $\begin{array}{l}\text { 13. Mate Miliša - Mijat - Primošten } \\
\text { (Caocesto) }\end{array}$ \\
\hline 14. Mijat Miliša - Grgur - Primošten & 15. Bože Milović - Ćiro - Knin \\
\hline 16. Andrija Opačić - Martin - Istra & 17. Risto Vuković - Šime - Drniš \\
\hline 18. Gligorije Calagni - Marko - Atlagići & 19. Josip Žunić - Mate - Žegar \\
\hline 20. Pavao Bastinović - Mate - Trogir & 21. Ignacije Torchella - Šime - Savar \\
\hline 22. Šime Modić - Miho & 23. Jakob Gicarze - Blaž - Kranjska \\
\hline 24. Jure Franšić - Grgo - Poreč & 25. Mijo Oliverić - Ivo - Crna Gora \\
\hline 26. Ivan Ercegović - Josip - Rogoznica & 27. Jure Sumić - Nikola - Vrana \\
\hline 28. Petar Trišić - Pavao - Zadar & 29. Andrija Kalegarić - Gligor - Dalmacija \\
\hline $\begin{array}{l}\text { 30. Toma Melisija - Mijo - Šibenik } \\
\text { (prekrižen) }\end{array}$ & 31. Luka Škobalj - Mate - Split \\
\hline 32. Martin Pauletić - Mate - Istra & $\begin{array}{l}\text { 33. Ivan Milok - Dominik - Istra } \\
\text { (prekrižen) }\end{array}$ \\
\hline 34. Ivan Petrović - Grga - Zadar & 35. Todor Stogerić - Ivan - Istra \\
\hline $\begin{array}{l}\text { 36. Grgo Došen - Marko - Rudanovac } \\
\text { (Lika) }\end{array}$ & 37. Jakov Kvarelić - Petar - Poljica \\
\hline 38. Grgo Vurtal - Antun - Trogir & $\begin{array}{l}\text { 39. Šime Kovačević - Miha - Islam } \\
\text { (prekrižen) }\end{array}$ \\
\hline 40. Miho Stude - Mate - Kaštela (prekrižen) & 41. Ivo Oliverić - Miho - Crna Gora \\
\hline $\begin{array}{l}\text { 42. Jure Oliverić (Oliverica) - Miho - Crna } \\
\text { Gora }\end{array}$ & \begin{tabular}{l} 
43. Jure Cenzar / Penzar - Ivan \\
\hline
\end{tabular} \\
\hline
\end{tabular}




\begin{tabular}{|l|l|}
\hline 44. Ivan Štekavić - Šimun - Istra & 45. Dominik Kovač - Frane - Dalmacija \\
\hline 46. Matija Corenti - Ivan - Poreč & $\begin{array}{l}\text { 47. Jozo Radović - Vicko - Kotor } \\
\text { (prekrižen) }\end{array}$ \\
\hline 48. Miho Arnaut - Aćim - Neretva & 49. Krsto Crnogorac - Šime - Neretva \\
\hline 50. Stipan Sircen - Frane - Neretva & $\begin{array}{l}\text { 51. Bartol Dulum/Dulam - Mihovil - } \\
\text { Neretva }\end{array}$ \\
\hline 52. Petar Arnaut - Aćim - Neretva & 53. Mate Dulum/Dulam - Nikola - Neretva \\
\hline 54. Ivan Dulum/Dulam - Toma - Neretva & 55. Miho Mašić - Antun - Neretva \\
\hline 56. Marijan Virnogn - Matija - Neretva & 57. Ivan Slusurić - Ante - Neretva \\
\hline 58. Matija Sunić - Mihovil - Neretva & 59. Miho Lentinić - Marko - Neretva \\
\hline 60. Jure Klupurić - Andrija - Neretva & 61. Mate Cluce - Mitar - Neretva \\
\hline 62. Ivan Jović - Stipan - Neretva (prekrižen) & 63. Jure Zorin - Lazar - Neretva \\
\hline 64. Boško Čulić - Petar - Neretva & 65. Mihovil Sturne - Ivan - Neretva \\
\hline 66. Ivan Sparčić - Ivan - Neretva (prekrižen) & $\begin{array}{l}\text { 67. Ćiro Novaković - Jure - kninsko } \\
\text { područje (territorio di Knin) }\end{array}$ \\
\hline 68. Bože Bilić - Pave - kninsko područje & 69. Mitar Ilić - Marko - kninsko područje \\
\hline $\begin{array}{l}\text { 70. Ivan Devarnja - Šime - kninsko } \\
\text { područje }\end{array}$ & 71. Grgur Vivorda - Petar - Sovinjak (Istra) \\
\hline 72. Jakov Gierman - Šimun - Sovinjak & 73. Matija Pinzan - Bartol - Sovinjak \\
\hline 74. Bastijan Etrotić - Martin - Sovinjak & 75. Dominik Sirotić - Jakov - Sovinjak \\
\hline 76. Ivan Gierman - Jakov - Sovinjak & 77. Ivan Černeka - Andrija - Sovinjak \\
\hline 78. Matija Sirotić - Stjepan - Sovinjak & 79. Ivan Sirotić - Toma - Sovinjak \\
\hline
\end{tabular}


Lovorka ČORALIĆ, Maja KATUŠIĆ

\section{JEROLIM SMEĆA - COLONEL IN VENETIAN OVERSEAS INFANTRY UNITS (SECOND HALF OF THE $18^{\mathrm{TH}}$ CENTURY)}

\section{SUMMARY}

Fanti Oltramarini, or the overseas infantry units, have for centuries been described as the most appreciated military units of Venetian Republic. The inhabitants of the wider area of the eastern Adriatic coast formed the majority in these units, ranging from soldiers to the highest officer ranks. In this paper, based on the study of the material kept at the Archivio di Stato di Venezia and the State Archives in Zadar, the military career of Jerolim Smeća from Boka stands in the very focus of research. The paper follows Smeća's way from cadet and ensign in the 1740s, over yearlong service as captain and major in infantry regiments of Benedikt Paskvali and Nikola Scutari, to the final years of the $18^{\text {th }}$ century, when Smeća obtained the rank of colonel. The paper pays special attention to the composition of companies in Smeća's command in individual stages of his career, and ends with transcripts of some of the lists of Smeća's military manpower in the period between 1765 and 1794 .

Keywords: Jerolim Smeća; Kotor; Venetian Republic; Fanti Oltramarini; military history; $18^{\text {th }}$ century. 